\title{
INVESTIGATION IN PROCESS OF FERMENTATION MEDIUM MIXING IN BIOREACTOR
}

\author{
Viktor Marchenko $^{1}$, Aleksandr Sorokin ${ }^{2}$, Dmitry Sidelnikov $^{1}$, Andrey Panasenko ${ }^{1}$ \\ ${ }^{1}$ Stavropol State Agrarian University, Russia; ${ }^{2}$ Kalmyk Research Institute of Agriculture \\ named after M. B. Narmaeva, Russia \\ marchenko59@mail,dimasud@yandex.ru
}

\begin{abstract}
The research of the specialists indicates that a promising direction of development of processing poultry droppings is the creation of low-waste or totally non-waste resource-saving production. It is based on the method of anaerobic fermentation of poultry droppings in bioreactors. One of the unsolved questions of bioreactor operation is the mixing process of fermentable substrate for the purpose to intensify the heat exchange in the amount of fermentation, because the performance of bioreactors depends on it. To study this process, we used the vertical bioreactor with an anchor stirrer, which is a classic example of the laboratory equipment in the study of intensification of heat exchange in viscous medium. It was found that the intensification of heat exchange in the fermentation medium is possible by replacing the free movement on its forced motion. And this movement is necessary to create within the thermal boundary layer that determines the laws of heat exchange. Criterion equation was obtained describing the heat exchange process, regardless of the mixing method. It was revealed that the motion condition of fermentation medium is characterized by the value of the Reynolds number. The number was determined characterizing the mixing intensity, which estimates the intensity of the mixing properties of the fermentation medium and constructive form of the bioreactor. We derived the equation of the heat exchange process operating at the forced motion of the fermentation medium in the boundary layer. The factors influencing on the heat exchange process in fermented poultry droppings. The performance of anaerobic bacteria are studied under the optimal intensification conditions of the mixing process of fermentation medium at the optimum concentration values of the dry organic substance and the fermentation temperature.
\end{abstract}

Keywords: bioreactor, anaerobic fermentation, poultry droppings, mixing device, temperature difference, biogas, heat exchange.

\section{Introduction}

The resource-saving technology of poultry droppings processing to obtain biogas, pelletized organic fertilizers, protein-vitamin concentrates and biologically-active fertilizers were developed at the Department of Machinery and Technology in Agro-industrial Complex (APC) of the Stavropol State Agrarian University [1]. This technology permits to process poultry droppings from poultry farms with cage keeping of poultry when humidity is $85-98 \%$. The process module is rated at processing 10 tons of poultry droppings per day.

The method of anaerobic fermentation under thermophilic conditions allowing to prepare poultry droppings for subsequent production of useful products was used as the base of the developed technology. As a result, mineralization of nitrogen, phosphorus, potassium, poultry droppings decontamination against pathogenic micro-flora, and total suppression of weed germination takes place [2].

The thermophilic condition requires greater expenditure of energy, and possesses considerable susceptibility to the temperature differences being confirmed by many specialists [3-6]. Therefore, the efficiency of the process of anaerobic fermentation will depend on the efficiency of heat conduction in the fermentation amount.

\section{Material and method}

Poultry droppings with $85-98 \%$ humidity was the object of our research. To carry out the research a pilot installation (a vertical cylindrical bioreactor) was mounted with capacity of $2 \mathrm{~m}^{3}$. A removable device as an anchor stirrer was mounted in it. The given stirrer together with the vertical bioreactor is a classic example of laboratory equipment when the process of heat conduction in the mediums similar to the studied raw materials is studied $[2 ; 6]$. The temperature sensors being in both vertical and horizontal planes were mounted to study the intensification process of heat exchange in the bioreactor. The control of temperature conditions took place by means of temperature regulators and equipment of automatic control. 


\section{The results of the research}

According to the source of information $[2 ; 6-8]$ intensification of heat exchange in the fermentation medium is possible with the replacement of free movement on stimulated, and within the thermal boundary layer $\delta$, which defines the heat exchange law. The given layer is formed not far from the heat source, in this case, near the heat jacket of the bioreactor being mounted on the external plate of the vertical bioreactor. To describe the heat exchange phenomena in the fermentation medium and to determine the heat exchange coefficient $\alpha$, the criterion equation describing this phenomenon in the geometrically similar bioreactor at poultry droppings fermentation was derived $[2 ; 6 ; 9]$ :

$$
N u=0.36 \cdot \operatorname{Re}_{c}^{0.67} \cdot \operatorname{Pr}^{0.33} \cdot \Gamma_{D}^{1.51} \cdot \operatorname{Vis}^{0.14},
$$

where $\mathrm{Nu}$ - Nusselt's criterion;

$R e_{c}$ - Reynolds's criterion;

$\mathrm{Pr}$ - Prandtl's criterion;

$\Gamma_{D}$ - invariant of geometric similarity equaled to the ratio of the diameter of the bioreactor to the diameter of the mixing device $\left(D \cdot d_{m}{ }^{-1}\right)$;

Vis - simplex viscosity of the bioreactor center of poultry droppings fermentation and boundary layer $\left(\mu \cdot \mu_{s}^{-1}\right)$.

After expansion of the criteria, similarity invariants, simplexes, a working equation was given to calculate the heat transfer coefficient in the fermented substrate:

$$
\frac{\alpha \cdot D}{\lambda}=0.36 \cdot\left(\frac{n \cdot d_{m}^{2} \cdot \rho}{\mu}\right)^{0.67} \cdot\left(\frac{\mu \cdot c}{\lambda}\right)^{0.33} \cdot\left(\frac{D}{d_{m}}\right)^{1.51} \cdot\left(\frac{\mu}{\mu_{c}}\right)^{0.14},
$$

where $\quad \alpha$-heat transfer coefficient, $\mathrm{W} \cdot\left(\mathrm{m}^{2} \cdot \mathrm{K}\right)^{-1}$;

$\lambda$ - heat conductivity coefficient, $\mathrm{W} \cdot(\mathrm{m} \cdot \mathrm{K})^{-1}$;

$D$ - bioreactor diameter, $\mathrm{m}$;

$n$ - rotational speed of mixing device, $\mathrm{s}^{-1}$;

$d_{m}$ - diameter of mixing device, $\mathrm{m}$;

$\rho$ - density of fermentable substrate, $\mathrm{kg} \cdot \mathrm{m}^{-3}$;

$\mu$ - dynamic viscosity coefficient, $\mathrm{Pa} \cdot \mathrm{s}$;

$c$ - heat capacity coefficient, $\mathrm{J} \cdot(\mathrm{kg} \cdot \mathrm{K})^{-1}$;

$\mu_{c}$ - dynamic viscosity wall layer coefficient, $\mathrm{Pa} \cdot \mathrm{s}^{-1}$.

According to the analysis of the criterion equation (1) we may come to the conclusion that with the increasing the number $R e_{c}$, the heat transfer coefficient of fermented medium increases. The given coefficient is a part of the Nuccelt criterion being a determinate to study the heat transfer process.

In this case, the value of the thermal boundary layer $\delta$ decreases and therefore the intensity of the heat exchange process increases. Thus, uniform temperature spreading in the capacity of fermentation increases the speed of the methane-genesis process.

To establish the productivity of bacteria in methane association in the above conditions at the optimum concentrations of dry organic substances (DOS) and temperature, the biogas yield from $1 \mathrm{~kg}$ of DOS poultry droppings was investigated. The peak value of biogas production is equal to $0.64 \mathrm{~m}^{3} \cdot \mathrm{kg}^{-1}$ DOS and is obtained at $15 \%$ concentration of DOS, the fermentation temperature $324 \mathrm{~K}$, the heat transfer coefficient in the fermentation poultry droppings is equal to $83.0 \mathrm{~W} \cdot\left(\mathrm{m}^{-2} \cdot \mathrm{K}^{-1}\right)$.

In accordance with the criterion equation (1), and describing the heat exchange process, regardless of the mixing method, the motion condition of the fermentation medium is characterized by the value of the Reynold's number $\left(R e_{c}\right)[6,10]$. The determining value of the motion is the rotation frequency $n$ (equation 2) of the mixing device, which is included in the Reynold's number. Obviously, with increasing $\mathrm{n}$ the number $R e_{c}$ will be increased, and hence the Nusselt number $(\mathrm{Nu})$, which characterizes the intensity of heat transfer in the fermentation medium [11].

However, with anaerobic fermentation of poultry droppings, it is not recommended to significantly increase the frequency of rotation of the mixing device, since, due to the biological features of the bacteria activity of methane-genic association, the movement speed of the fermentation 
medium should not exceed $0.5 \mathrm{~m} \cdot \mathrm{s}^{-1}$ [12]. In the experiments, the linear speed of the anchor stirrer did not exceed this value and varied within the limits of $0.13 \ldots 0.4 \mathrm{~m} \cdot \mathrm{s}^{-1}$.

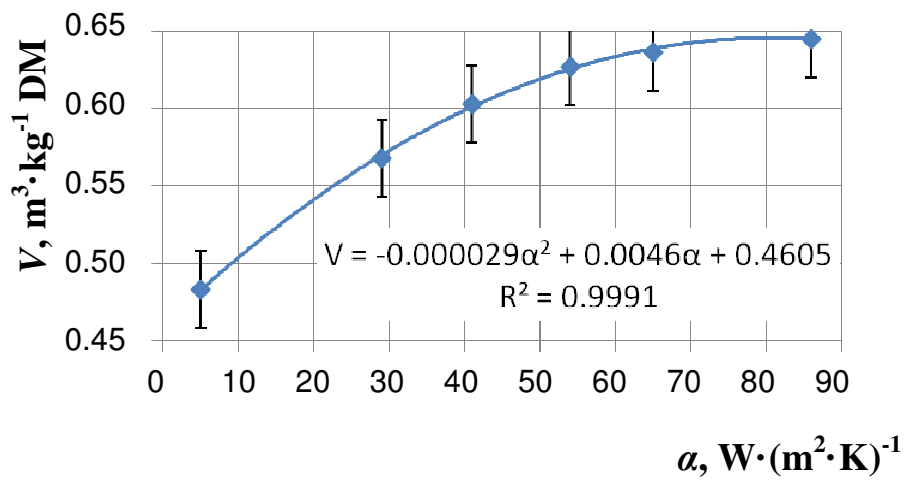

\section{Fig. 1. Biogas production $V$ depending on the heat transfer coefficient $\alpha$ in the amount of poultry droppings fermentation in the bioreactor}

In addition, for a fixed value of the speed of the mixing device, the homogeneity of the system is also affected by the mixing time $(\tau)$. The joint effect of these quantities is usually represented as a complex $(\tau \cdot n)$, which expresses the number of revolutions of the mixing device [13; 14].

Fig. 2 shows the curves characterizing the change in the temperature difference of the amount of fermented poultry droppings at the values of the motion speeds of the mixing device $W_{1}=0.13 \mathrm{~m} \cdot \mathrm{s}^{-1}$, $W_{2}=0.20 \mathrm{~m} \cdot \mathrm{s}^{-1}, W_{3}=0.27 \mathrm{~m} \cdot \mathrm{s}^{-1}, W_{4}=0.40 \mathrm{~m} \cdot \mathrm{s}^{-1}$. According to the nature of the obtained graphical dependences, we may come to the conclusion that mixing occurs most intensively at the movement speed of the fermented poultry droppings close to the maximum permissible and equal to $0.4 \mathrm{~m} \cdot \mathrm{s}^{-1}$. Moreover, the energy consumption at this speed is the least. This is confirmed by the graph (Fig. 3), which reflects the dependence of the energy consumption of the mixing device on its speed.

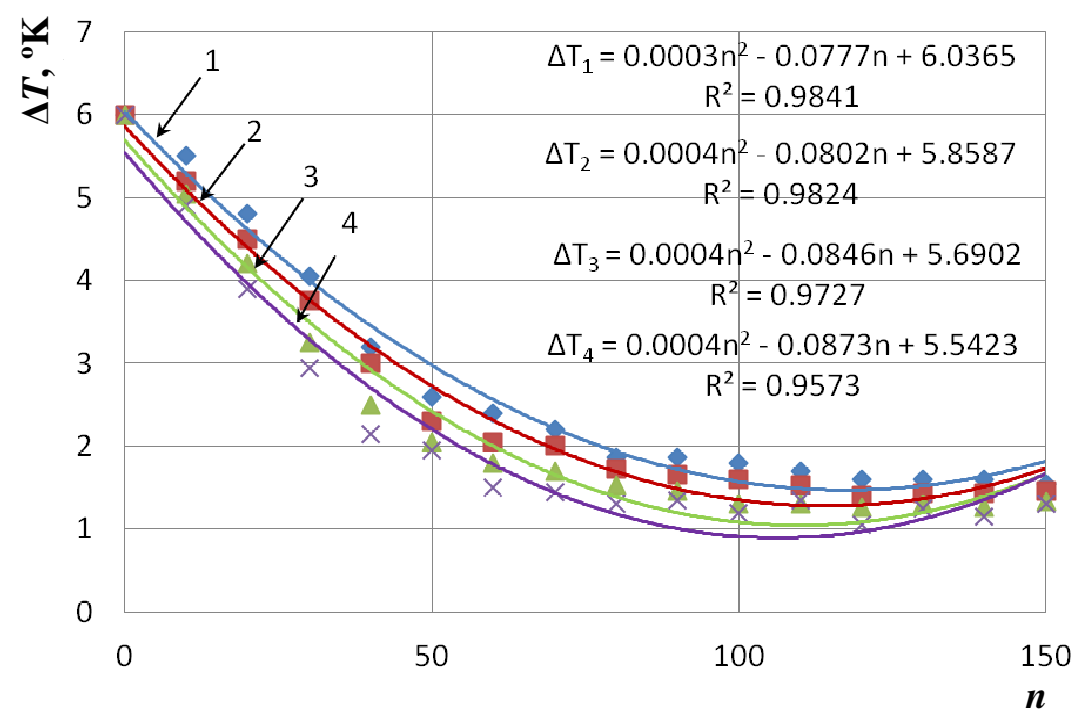

Fig. 2. Dependence of the temperature difference $\Delta T$ of fermented poultry droppings on the revolution numbers of the mixing device $(\tau \cdot n)$

When the fermentation medium is mixed at a speed of $0.4 \mathrm{~m} \cdot \mathrm{s}^{-1}$ after 50 revolutions of the anchor stirrer, the temperature difference in the amount of fermentation decreases and the value \pm 3 is achieved. The given result does not correspond to the requirement of the production process of anaerobic fermentation in the thermophilic condition [12]. After 80 revolutions, the temperature difference decreases up to the acceptable value and is \pm 1.5 , which corresponds to the production requirements of the process.

Further mixing has no appreciable effect on this value. This indicates a decrease in the intensity of the effect of the mixing device on the fermentation medium, and also confirms the characteristic of the mixing process, which is common to many investigators $[7 ; 8 ; 14 ; 15]$, equal to a constant value, i.e. 


$$
\tau \cdot n=C^{\prime},
$$

where $C^{\prime}-$ constant, depending on the properties of the fermented poultry droppings and the constructive shape of the stirrer.

Corresponding to the growth of the temperature uniformity of the fermentation medium, depending on the intensity of mixing, the heat transfer coefficient $\alpha$ increases, which determines the heat spreading speed in the amount of fermented poultry droppings.

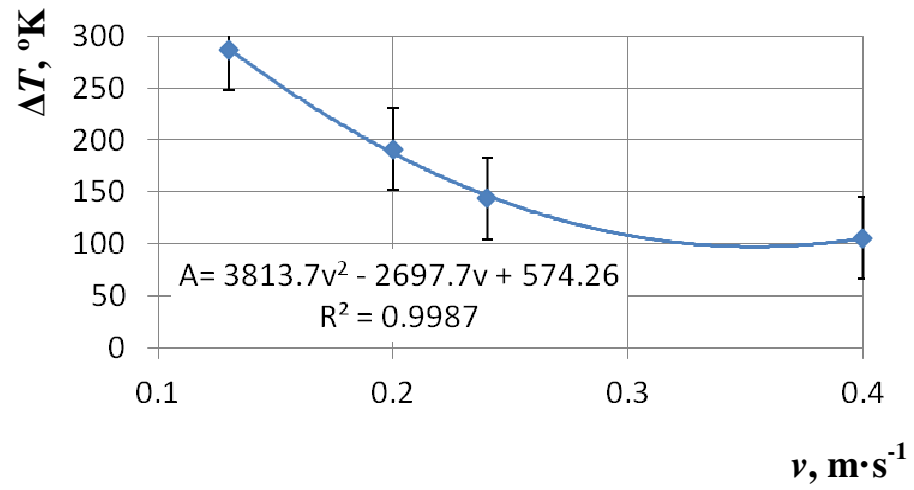

Fig. 3. Dependence of energy expenditure $A$ when mixing fermented poultry droppings on the movement speed of the mixing device $v$

The obtained values of the biogas production value depending on the uniformity of the temperature field are confirmed by the studies of other researchers [16-18]. Thus, it is established that the maximum process productivity of methane fermentation is achieved in the amount of the bioreactor with the maximum uniform temperature field. For this, it is necessary that the following conditions will be fulfilled:

$$
\Delta T / \Delta h \rightarrow 0 \text { and } \Delta T / \Delta r \rightarrow 0,
$$

where $\Delta h$-temperature difference in fermented medium by bioreactor height, $\mathrm{m}$; $\Delta r$ - temperature difference in fermented medium by bioreactor radius, $\mathrm{m}$;

At which the temperature at all points of the amount of fermented poultry droppings is practically identical:

$$
T_{1} \equiv T_{2} \equiv T_{3} \equiv \ldots \equiv T_{n} \equiv T_{o p t} .
$$

In this case, it can be seen that the maximum temperature homogeneity of the fermentation medium, which is defined by minimally possible deviation of the local temperature $\left(T_{i}\right)$ in the amount of the bioreactor from the optimal fermentation temperature value $\left(T_{\text {opt }}\right)$, i.e.

$$
T_{i}-T_{\text {opt }}=\Delta T \rightarrow 0 .
$$

The production of a uniform temperature field in the amount of fermentation is inextricably linked with the efficiency of the mixing devices. The effectiveness of F. Strenk's mixing [19] is determined by the amount of the energy spent on mixing to achieve the required production effect. Since, in practice, different types of bioreactors and many types of mixing devices are used to intensify the heat transfer process, therefore this criterion cannot be used as a general assessment of the work of the latter.

According to many researchers $[8 ; 13 ; 15]$, the mixing process is characterized by the quality of mixing, on the other hand. It is obvious that the quality of mixing with the intensification of heat exchange processes is characterized by the degree of temperature homogeneity of the mixed fermented medium, which is determined by the value:

$$
1-\Delta T / T_{o p t}=T / T_{o p t} .
$$

As a rule, the degree of temperature uniformity of the mixed medium is determined by the conditions of the production process. The period, which is necessary to achieve a given temperature 
homogeneity of the medium, is called the mixing time. The mixing time is directly determined by the circulation multiplicity and the degree of turbulence of the mixed medium:

$$
\tau=\frac{K_{c} \cdot V}{Q_{c}},
$$

where $\tau$ - mixing time, c;

$K_{c}$ - multiplicity of circulation;

$V$ - working volume of mixed medium, $\mathrm{m}^{3 ;}$

$Q_{c}$ - volumetric circulation flow, $\mathrm{m}^{3} \cdot \mathrm{s}^{-1}$.

The circulation ratio of mixed medium determines the number of the amount of fermented medium passing through a cross section of cylindrical capacity of the bioreactor. So, the given value is universal and it can be used to calculate the stabilization of temperature homogeneity for all used mixing devices in different types of bioreactors [8; 13; 19].

Due to the peculiarities of the biological development of the bacteria of methanogenic association [12], the degree of turbulence has a value and has no effect on these peculiarities. So, it does not impact the time of mixing. Thus, the mixing time $\tau$, and, consequently, the degree of temperature homogeneity of the $T / T_{o p t}$ of the fermented droppings depend on the multiplicity of the circulation of $K_{c}$ in the bioreactor:

$$
T / T_{\text {opt }}=f\left(K_{c}\right) .
$$

The theoretical homogeneity temperature of the mixed medium $\left(T / T_{o p t}=1\right)$ is achieved for circulation numbers tending to infinity $\left(K_{c} \rightarrow \infty\right)$. In practice, the required amount of circulation depends on the conditions of the process. The technologically acceptable degree of temperature homogeneity corresponds to a value of 0.96 and higher $[13 ; 19]$.

As it was established, in the amount of fermented poultry droppings the degree of temperature uniformity ranges from 0.798 to 0.970 [1]. The main influence on $T / T_{\text {opt }}$ is the value of the concentration of DOS in the poultry droppings.

In order to determine the value of the multiplicity of the circulation of $\mathrm{Kc}$, which affects the mixing time $\tau$ and energy consumption, and to determine the dependence of the degree of temperature homogeneity of $T / T_{\text {opt }}$ on the concentration of DOS in poultry droppings $c$, studies were carried out on a laboratory unit with a total volume of $2 \mathrm{~m}^{3}[6 ; 9]$.

The results of the studies were processed by the method of least squares using the standard program package on the IBM computer. As a result, the dependencies described by the equations are obtained:

$$
\begin{gathered}
T / T_{\text {opt }}=1.01-0.0087 \cdot c, \\
K_{c}=45.628-46.79 \cdot T / T_{o p t} .
\end{gathered}
$$

As it can be seen from the obtained dependence (Fig. 4), the multiplicity of circulation $K_{c}$ of the fermented poultry droppings varies significantly: from 0.7 to 8.8 . So, with the value of the concentration of DOS in the poultry droppings equal to $2 \%$, the degree of temperature homogeneity of $T / T_{\text {opt }}$ satisfies the required technological effect and is equal to 0.97 (Fig. 5). In this case, the fermented poultry droppings are similar to the liquid medium quality where the value of the thermal boundary layer $\delta$ can be neglected and, therefore, it is not necessary to mix it.

With an increase in the concentration of DOS in the droppings from $5 \%$ to $8 \%$ in the amount of fermentation, there are forces of internal interaction that prevent heat spreading through free movement. The degree of temperature homogeneity of $T / T_{\text {opt }}$ decreases to a value $\left(T / T_{\text {opt }}=0.931\right)$ below the technologically required one, so mixing is used to overcome the forces of internal interaction. Moreover, the value of the multiplicity of the circulation of the $K_{c}$ sharply increases from zero to 3.2 . 


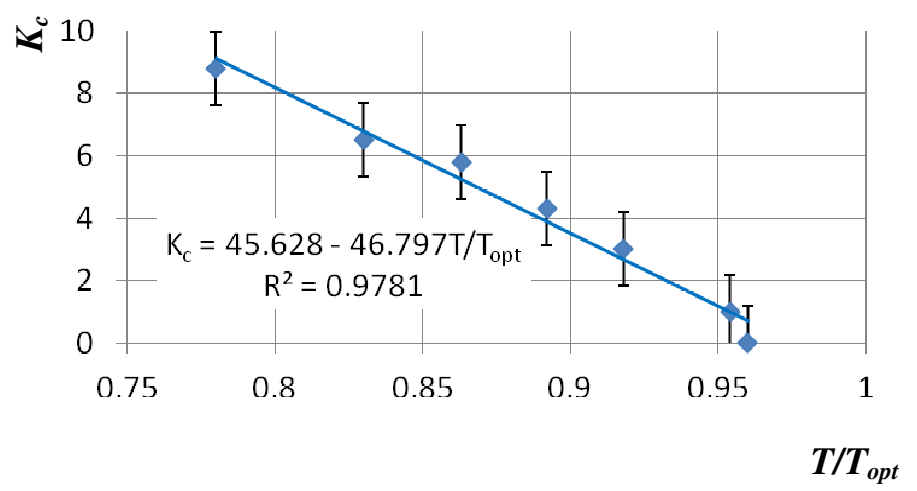

Fig. 4. Dependence of the degree of temperature inhomogeneity $T / T_{o p t}$ on the multiplicity of circulation $K_{c}$

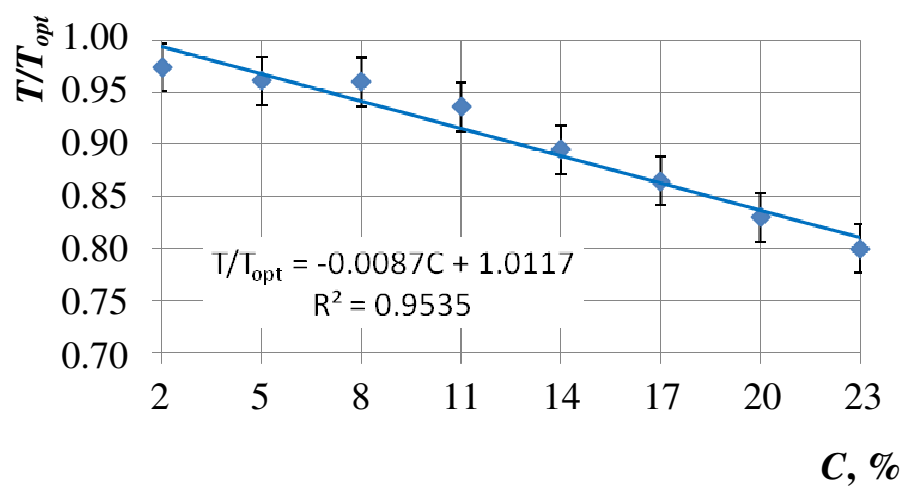

Fig. 5. Dependence of the degree of temperature inhomogeneity of $T / T_{o r t}$ on the concentration of DOS $c$ from the fermented poultry droppings

A further increase in the concentration of DOS in the droppings from $8 \%$ to $17 \%$, significantly reduces the degree of temperature uniformity $T / T_{\text {opt }}$ to a value of 0.870 . In this range of DOS concentrations, fermented poultry droppings resemble an amorphous body, in which heat spreading predominates in thermal conductivity. Therefore, in order to achieve a technologically prescribed degree of temperature homogeneity $T / T_{o p t}$, the circulation ratio $K_{c}$ gradually increases to a value of 5.0.

With an increase in the concentration of DOS in the droppings to $24 \%$, the latter loses its ability to separate into liquid and solid fractions and the degree of temperature homogeneity of $T / T_{o p t}$ decreases sharply to 0.798 . To achieve the value of $T / T_{o p t}$ of the technologically required value of 0.96 , the circulation ratio $K_{c}$ is increased and its value is 8.0.

\section{Conclusions}

Anaerobic fermentation of poultry droppings under thermophilic conditions requires more qualitative adhearance to the specifications of temperature conditions. It is possible with intensification of the heat exchange process by mixing the fermented medium;

The value, which determines the intensification of heat exchange in the amount of fermentation, is the degree of temperature homogeneity;

As different types of mixing devices are used for intensification of heat exchange in the amount of the bioreactor, we chose the universal measure of all types of mixing devices - circulation ratio;

Circulation ratio allows to determine the circulation of fermented medium through the bioreactor cross independent on the used mixing devices.

\section{References}

1. Марченко В.И., Алексеенко В.А., Сидельников Д.А., Сляднев Д.Н. Ресурсосберегающая технология переработки отходов птицеводства (Resource-saving technology of processing of poultry waste). Mechanization and electrification of agriculture. 2010. № 1. pp. 8-10. (In Russian). 
2. Марченко В.И. Обоснование параметров и режимов интенсификации процесса анаэробного сбраживания помета: (Justification of parameters and modes of process intensification of anaerobic digestion of manure) дис. канд. техн. наук. Ставропольский государственный аграрный университет. Ставрополь, 1997. 182 p. (In Russian).

3. Дубровский В.С., Виестур У.Э. Метановое сбраживание сельскохозяйственных отходов. (Methane fermentation of agricultural waste). - Рига: Зинатне, 1988. pp. 160-168. (In Russian).

4. Хенце М. и др. Очистка сточных вод. Биологические и химические процессы: (Wastewater treatment. Biological and chemical processes) пер. с англ. / М. Хенце, П. Армоэс, Й. Ля-КурЯнсен, Э. Арван. - М.: Мир, 2008. 471 p (In Russian).

5. Мяята Р.К. Анаэробное сбраживание и его применение (Anaerobic digestion and its application) // Biogas-85. Problems and solutions. Materials of the Soviet-Finnish Symposium. Moscow-Helsinki, 1985, pp. 36-46 (In Russian).

6. Марченко В.И. и др. Исследование теплообмена в биореакторе свободного движения (Тhe study of heat transfer in the bioreactor the free movement) - Mechanization and electrification of agriculture. 2007. № 7. pp. 27-28.

7. Брагинский Л.Н., Бегачев В.И., Барабаш В.М. Перемешивание в жидких средах (Mixing in liquid media).- Л.:Химия, 1984.- 336 р. (In Russian).

8. Кафаров В.В. и др. Перемешивание на микро- и макроуровнях в процессе ферментации (Mixing on the micro and macro levels in the fermentation process). - M., 1974. 157 p. (In Russian).

9. Марченко В. И. Оптимизация процесса перемешивания при анаэробном сбраживании отходов птицеводства (Optimization of the mixing process in anaerobic digestion of poultry waste) Vestnik APK Stavropol, 2011. - № 1. - pp. 53-56. (In Russian).

10. Ways to intensify the process of anaerobic digestion of poultry manure in a bioreactor / Marchenko V.I., Sidelnikov D.A., Gritsai D.I., Gerasimov E.V., Shvetsov I.I. / Research Journal of Pharmaceutical, Biological and Chemical Sciences. 2016. T. 7. №3. C. 1913-1918.

11. Исаченко В.П., Осипова В.А., Сукомел А.С. Теплопередача (Heat transfer). - М.: Энергоиздат, 1981. 416 p. (In Russian).

12. Крепис И.Б. Возможности и перспективы получения энергии с помощью метанового брожения (Opportunities and prospects of energy production through methane fermentation) Изв. АН CCCP. - 1979. - Вып. 1. pp. 275-284. (In Russian).

13. Васильцов Э.А., Ушаков В.Г. Аппараты для перемешивания жидких сред (Apparatus for mixing liquid media). - М.: Машиностроение, 1979. - 272 р. (In Russian).

14. Зигмунд Ф.Ф., Часовский Е.З. Изучение эффективности перемешивания механическими мешалками в условиях теплового импульса (Study of the efficiency of stirring with a mechanical stirrer under conditions of a heat pulse)// Труды КХТИ. - 1962. - Вып. 30. - Р. 329340. (In Russian).

15. Юдахин Е.С. Исследование теплообмена при перемешивании концентрированных суспензий в аппаратах с мешалками (Study of heat transfer during mixing of concentrated suspensions in the apparatus with stirrer): автореф. дис. ... канд. техн. наук. Уфа, 1979. -15 p. (In Russian).

16. Bousfield S., Hobson P.N., Summers R. A note on anaerobic digestion of cattle and poultry wastes // Agr. Wastes.-1979. - Vol.1, No.2. - P.161-164.

17. Chen J.R., Varel V.H., Hashimoto A.G. Effect of temperature on methane fermentation kinetics of beef cattle rnanure//BiotechnolBioeng\&Symp. - 1980. - No. 10. .325 p.

18. Hashimoto A.G. Thermophilic and mesophilic anaerobic fermentation of swine manure // Agr. Wastes.-1983. - Vol.6. - pp.175-191.

19. Стренк Ф. Перемешивание и аппараты с мешалками (Mixing and apparatus with mixers) . Л.: Химия, 1975. - 384 p. (In Russian).

20. Штербачек 3., Дауск П. Перемешивание в химической промышленности (Mixing in the chemical industry). - Л.: Госхимиздат, 1963. - 416 p. (In Russian). 